\title{
Synergistic Solvent Extraction of Lanthanides(III) with Mixtures of 4-Benzoyl-3-Methyl-1-Phenyl-5-Pyrazolone and Phosphoryl-Containing Podands
}

\author{
Alexander Nikolaevich Turanov, ${ }^{1}$ Vasilii Konstantinovich Karandashev, ${ }^{2,3}$ \\ Vladimir Evgenevich Baulin, ${ }^{4 \star}$ Dmitriy Vladimirovich Baulin ${ }^{5}$ \\ and Aslan Yusupovich Tsivadze 5 \\ ${ }^{1}$ Institute of Solid State Physics, Russian Academy of Sciences, 142432 Chernogolovka, Russia \\ ${ }^{2}$ Institute of Microelectronics Technology and High Purity Materials, Russian Academy of Sciences, \\ 142432 Chernogolovka, Russia \\ ${ }^{3}$ National University of Science and Technology MISiS, 119049, Moscow, Russia \\ ${ }^{4}$ Institute of Physiologically Active Compounds, Russian Academy of Sciences, Chernogolovka, \\ Moscow Region, 142432 Russia \\ ${ }^{5}$ Frumkin Institute of Physical Chemistry and Electrochemistry, Russian Academy of Sciences, Moscow, 119991 Russia \\ *Corresponding author: E-mail: mager1988@gmail.com
}

Received: 07-02-2019

\begin{abstract}
The solvent extraction of La, Ce, Pr, Nd, Sm, Eu, Gd, Tb, Dy, Ho, Er, Tm, Yb, and Lu from weak acidic chloride solutions into an organic phase containing 4-benzoyl-3-methyl-1-phenyl-5-pyrazolone (HP) and phosphoryl-containing podands (L) has been studied. A considerable synergistic effect was observed in the presence of neutral ligands L in the organic phase containing HP. The stoichiometry of the $\operatorname{Ln}(\mathrm{III})$ extracted species was determined by slope analysis and the equilibrium constants were calculated. It was found that the lanthanide(III) ions are extracted with mixtures of HP and neutral ligands in toluene from weak acidic solutions as $\mathrm{LnLP}_{3}$ complexes.
\end{abstract}

Keywords: Lanthanides(III); synergistic extraction; 4-benzoyl-3-methyl-1-phenyl-5-pyrazolone; phosphoryl-containing podands.

\section{Introduction}

Solvent extraction is a widely used technique for the separation and preconcentration of lanthanide(III) ions. A synergistic effect, a non-additive increase in the distribution ratios of metal ions, is often used to increase the efficiency of the extraction of metal ions. ${ }^{1-3}$ The synergistic effect in solvent extraction systems is due to an increase in the hydrophobicity of extracted species as a result of replacement of water molecules bound to the metal ion by molecules of a synergistic compound. ${ }^{3}$ The application of mixtures of an acidic chelating extractant and a neutral donor is one of the most thouroughly studied synergistic extraction processes. During the last few decades, the syn- ergistic extraction of lanthanides(III) with mixtures of acidic chelating extractants such as $\beta$-diketones, 4 -acylpyrazolones, 4-acyl-5-izoxazolone, etc. and neutral donor extractants (e.g. nitrogen-containing compounds, ${ }^{4-6}$ sulfoxides, ${ }^{7,8}$ crown ethers, ${ }^{3,9-11}$ diglycolamides, ${ }^{12}$ neutral mono- and polydentate organophosphorus compounds, ${ }^{13-20}$ etc.) has been studied. Many studies have been carried out using phosphorus-containing calix $[n]$ arenes as a synergistic agent at the $\operatorname{Ln}$ (III) extraction with various acidic chelating extractants of $\beta$-diketone type. ${ }^{21-}$ ${ }^{26}$ The introduction of $\mathrm{P}(\mathrm{O})$ functional groups in the calixarene architecture leads to a significant increase in the extraction efficiency. ${ }^{26}$ The addition of phosphorus-containing calix[6]arene to the chelating extractant, 4-benzoyl-3- 
methyl-1-phenyl-5-pyrazolone, improves the Ln(III) extraction and produces very large synergistic effects (more than five orders of magnitude). ${ }^{25}$

Recently, a great interest has arisen in the use of acyclic analogues of crown ethers (podands), as extractants. The complexation ability of a linear polyether ligand can be markedly increased by replacing its terminal alkyl groups with amide or phosphoryl groups. ${ }^{27,28}$ Phosphoryl-containing podands have high extraction abilities for metal ions due to the ability of flexible podand molecules to acquire pseudo-macrocyclic conformation upon complexation. ${ }^{29}$ The main factors determining the efficiency of metal ion extraction with phosphoryl-containing podands are the donor ability of phosphoryl oxygen atoms, the length of the polyether chain, and the nature of the moiety linking it to the phosphoryl group. ${ }^{30}$

In this work, we study the effect of structure of phosphoryl-containing podands I-VII on the extraction of Ln(III) ions with 4-benzoyl-3-methyl-1-phenyl-2-pyrazolin-5-one (HP) in organic diluents and determine the composition of the extracted complexes of $\operatorname{Ln}(\mathrm{III})$. The extraction behavior of the above ligands is compared with that of 2-(2-(diphenylphosphoryl)phenoxy)-N,N-dioctylacetamide VIII and monodentate neutral extractant, triphenylphospine oxide (TPhPO). ${ }^{31}$ The structural formulae of the extractants studied are given below. phenyl-5-pyrazone (purity $>99 \%$, Vekton) were used as received. Chemical- and analytical-grade chloroform, 1,2-dichloroethane and toluene were used as diluents. (2-((Diphenylphosphoryl)methoxy)phenyl)diphenylphosphine oxide (II), (2-((diphenylphosphoryl)-4-ethylphenoxy)methyl)diphenylphosphine oxide (III), (2-(2-(diphenylphosphoryl)-4-ethylphenoxy)ethyl)diphenylphosphine oxide (IV), (2-(3-(diphenylphosphoryl) propoxy)phenyl)diphenylphosphine oxide (V) and ((2-(diphenylphosphoryl)ethoxy)methyl)diphenylphosphine oxide (VII) were synthesized as described. ${ }^{33-35}$ Their physical constants and data on elemental analysis and NMR spectra were in agreement with the published data.

\section{2. Synthesis of the Extragents}

2-(Diphenylphosphoryl)phenyldiphenylphosphinate (I). A mixture of $6.40 \mathrm{~g}(21.74 \mathrm{mmol})$ of (2-hydroxyphenyl)diphenylphosphine oxide, ${ }^{32} 1.69 \mathrm{~g}(21.74 \mathrm{mmol})$ of dry pyridine, $5.12 \mathrm{~g}(21.74 \mathrm{mmol})$ of diphenylphosphinic chloride and $50 \mathrm{~mL}$ of dry benzene was mixed on magnetic stirrer at the temperature of $80^{\circ} \mathrm{C}$ for $6 \mathrm{~h}$. Then the reaction mixture was poured into water, extracted by benzene $(4 \times 30 \mathrm{~mL})$, the organic extracts were rinsed with $20 \%$ $\mathrm{HCl}$ solution $(3 \times 30 \mathrm{~mL})$, water $(3 \times 30 \mathrm{~mL})$, dried by<smiles>[R]c1ccc(OCC)c(P(=O)(c2ccccc2)c2ccccc2)c1P(=O)([In])c1ccccc1</smiles>

I: $\mathrm{R}=\mathrm{H}, \mathrm{n}=0$; II: $\mathrm{R}=\mathrm{H}, \mathrm{n}=1$;

III: $\mathrm{R}=\mathrm{Et}, \mathrm{n}=1 ; \mathbf{I V}: \mathrm{R}=\mathrm{Et}, \mathbf{n}=2$; $\mathbf{V}: \mathrm{R}=\mathrm{H}, \mathrm{n}=3$<smiles>CCON(OCl)C(=O)COc1ccc(CC)cc1P(=O)(c1ccccc1)c1ccccc1</smiles>

VIII

\section{Experimental}

\section{1. Materials and Methods}

The commercial products triphenylphosphine oxide (purity > 99\%, Chemapol) and 4-benzoyl-3-methyl-1-<smiles>O=P(COc1ccccc1P(=O)(c1ccccc1)c1ccccc1)(c1ccccc1)c1ccccc1</smiles><smiles>O=P(CCOCP(=O)(c1ccccc1)c1ccccc1)(c1ccccc1)c1ccccc1</smiles>

VI<smiles>CC1=NN(c2ccccc2)C(=O)C1C(=O)c1ccccc1</smiles>

HP

$\mathrm{MgSO}_{4}$. After evaporation, the residue was crystallized from benzene' - hexane mixture. The yield of I was $7.23 \mathrm{~g}$ (69\%), m.p. $175-177^{\circ} \mathrm{C}$. Anal. Calcd. for $\mathrm{C}_{30} \mathrm{H}_{24} \mathrm{O}_{3} \mathrm{P}_{2}$ (\%): C, 72.87; H, 4.89; P 12.53. Found (\%): C, 72.93; H, 4.90; P, 12.56. ${ }^{1} \mathrm{H} \mathrm{NMR}\left(\mathrm{CDCl}_{3}\right): \delta: 7.01-7.28(2 \mathrm{H}, \mathrm{m}, \mathrm{Ar}-\mathrm{H})$, 7.33-7.56 (12H, m, Ar-H), 7.63-7.90 (10H, m, Ar-H). ${ }^{31} \mathrm{P}$ 
$\operatorname{NMR}\left(\mathrm{CDCl}_{3}\right): \delta: 28.72,32.25$.

(2-((diphenylphosphoryl)methoxy)benzyl)diphenylphosphine oxide (VI). A mixture of $3.22 \mathrm{~g}$ (10.00 mmol) 2-(hydroxybenzyl)diphenylphosphine oxide $3.86 \mathrm{~g}$ (10.00 mmol) (diphenylphosphoryl)methyl-4-methylbenzenesulphonate and $2.26 \mathrm{~g}(10.00 \mathrm{mmol})$ anhydrous cesium carbonate in $35 \mathrm{~mL}$ of dry dioxane was heated and stirred at $100{ }^{\circ} \mathrm{C}$ for $8 \mathrm{~h} .{ }^{36}$ The reaction mixture was diluted by $75 \mathrm{~mL}$ of water, acidified by adding concentrated $\mathrm{HCl}$ to $\mathrm{pH} 1$, and extracted by $\mathrm{CHCl}_{3}(3 \times 25 \mathrm{~mL})$. The organic layer was separated, washed with water, and evaporated under reduced pressure to give crude product VI. It was purified by column chromatography on silica gel 100$160 \mathrm{~mm}$, the eluents $\mathrm{CHCl}_{3}$ and $\mathrm{CHCl}_{3} / i-\mathrm{PrOH}(10: 1)$. The yield of VI was $4.04 \mathrm{~g}(77 \%)$, m.p. $168-169.5^{\circ} \mathrm{C}$. Anal. Calcd. for $\mathrm{C}_{32} \mathrm{H}_{28} \mathrm{O}_{3} \mathrm{P}_{2}$ (\%): C, 73.56; H, 5.40; P 11.86 . Found (\%): C, 73.40; $\mathrm{H}, 5.34 ; \mathrm{P}, 11.69 .{ }^{1} \mathrm{H} \mathrm{NMR}\left(\mathrm{CDCl}_{3}\right)$ :

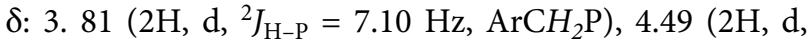
${ }^{2} J_{\mathrm{H}-\mathrm{P}}=5.18 \mathrm{~Hz}, \mathrm{OCH}_{2} \mathrm{P}(\mathrm{O}), 7.00-7.32(2 \mathrm{H}, \mathrm{m}, \mathrm{Ar}-\mathrm{H})$, 7.35-7.56 (12H, m, Ar-H), 7.61-7.92 (10H, m, Ar-H). ${ }^{31} \mathrm{P}$ $\operatorname{NMR}\left(\mathrm{CDCl}_{3}\right): \delta: 28.15,32.15$.

\section{3. Apparatus}

An X-7 mass spectrometer with a quadrupole mass analyzer (Thermo Electron, USA) was used for measurement of lanthanides concentration and $\mathrm{pH}-150$ digital $\mathrm{pH}$ meter was used for $\mathrm{pH}$ measurements. The ${ }^{1} \mathrm{H}$ and ${ }^{31} \mathrm{P}$ NMR spectra were recorded on a Bruker DXP-200 spectrometer with Fourier transform using tetramethylsilane $\left({ }^{1} \mathrm{H}\right.$, internal) and $85 \% \mathrm{H}_{3} \mathrm{PO}_{4}\left({ }^{31} \mathrm{P}\right.$, external $)$ as standard. Elemental analyses were performed using a Perkin-Elmer $240 \mathrm{C}$ analytical instrument.

\section{4. Solvent Extraction Procedure}

Stock solutions of the lanthanide(III) ions were prepared from their oxides by dissolving in concentrated hydrochloric acids and diluting with deinonized water to the required volume. All the lanthanides (III) (except Pm) were present in the initial aqueous phase when simultaneous extraction of $\operatorname{Ln}(\mathrm{III})$ was studied. The ionic strength was maintained at $0.1 \mathrm{M}$ with $\mathrm{NaCl}$ and $\mathrm{HCl}$. The initial lanthanide ions concentration was $2 \times 10^{-6} \mathrm{M}$ for each element. Extractant solutions in the organic diluents were prepared from precisely weighed amounts of the reagents.

Equal volumes $(2 \mathrm{~mL})$ of the aqueous and organic phases were shaken mechanically for $60 \mathrm{~min}$ at $22 \pm 1{ }^{\circ} \mathrm{C}$, which was sufficient to reach equilibrium. After phase separation, $1 \mathrm{~mL}$ of the aqueous solution was taken for further analysis. A portion of the organic phase was transferred to another glass tube, and a specific volume of $1 \mathrm{M} \mathrm{HCl}$ solution was added. The mixture was shaken for $30 \mathrm{~min}$ and $\mathrm{Ln}(\mathrm{III})$ in the organic phase was extracted back into the aqueous phase.
Concentrations of $\operatorname{Ln}(\mathrm{III})$ in the initial and equilibrium aqueous solutions after extraction and back-extraction were determined by inductively coupled plasma mass-spectrometry (ICP-MS). The sum of the metal ion concentrations in the two phases agreed well with the initial concentration. The distribution ratios of lanthanides $\left(D_{\mathrm{Ln}}\right)$ were calculated as the ratio of concentrations in the equilibrium organic and aqueous phases. Triplicate experiments showed that the reproducibility of the $D_{\text {Ln }}$ measurements was generally within $5 \%$. The acidity of the aqueous phase was measured by a $\mathrm{pH}$-meter with an accuracy of $0.01 \mathrm{pH}$ units.

\section{Results and Discussion}

\section{1. Extraction of Lanthanide(III) Ions with Mixtures of HP and Neutral Ligands I- VIII}

There have been many reports on solvent extraction of lanthanide(III) ions with 4-acylpyrazolones. ${ }^{37}$ The lanthanides(III) extraction with 4-benzoyl-3-methyl-1-phenyl-5-pyrazolone (HP) alone in organic diluents was previously studied by Dukov et al. ${ }^{38,39}$ They found that the metal ions are extracted as self-adducts $\mathrm{LnP}_{3} \mathrm{HP}$ and their extraction can be described by the equation:

$$
\mathrm{Ln}^{3+}{ }_{(\mathrm{aq})}+4 \mathrm{HP}_{(\mathrm{org})} \rightleftharpoons \mathrm{LnP}_{3} \mathrm{HP}_{(\text {org })}+3 \mathrm{H}^{+}{ }_{(\mathrm{aq})}
$$

where the subscripts "aq" and "org" denote the aqueous and organic phases, respectively.

The corresponding extraction constant $\mathrm{K}_{\mathrm{P}}$ is

$$
\mathrm{K}_{\mathrm{P}}=D_{\mathrm{Ln}}\left[\mathrm{H}^{+}\right]_{(\mathrm{aq})}^{3}[\mathrm{HP}]^{-4}(\mathrm{org})
$$

Preliminary experiments showed that the lanthanides(III) extraction with compounds I-VII and TPhPO alone is negligible under the experimental conditions of the present study. However, a considerable enhancement of the Ln(III) extraction with HP in the presence of these compounds in the organic phase was observed.

To compare the extraction efficiency of neutral donor compounds, a simultaneous extraction of $\operatorname{Ln}(\mathrm{III})$ ions from aqueous solutions with mixtures of HP and compounds I-VIII and TPhPO in 1,2-dichloroethane was studied (Figure 1). These experiments showed that the efficiency of $\operatorname{Ln}(\mathrm{III})$ synergistic extraction with compounds of phosphine oxide type (II-VII) is higher than that of compound I of phosphinate type. This can be due a weakening donor ability of $\mathrm{P}(\mathrm{O})$ group of compound $\mathrm{I}$ as compared with compounds II-VII. The efficiency of $\operatorname{Ln}(\mathrm{III})$ synergistic extraction with compounds II-VII is higher than that of monodentate TPhPO (Figure 1). Therefore, an increase of a number of $\mathrm{P}(\mathrm{O})$ groups in the compounds II-VII molecule leads to an increase in the $D_{\mathrm{Ln}}$ values. 


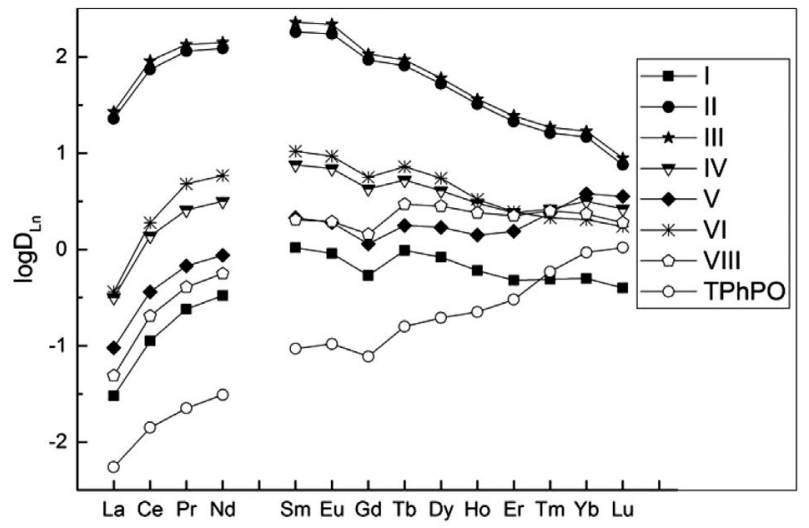

Figure 1. The extraction of lanthanides(III) with HP-compounds I-VIII and TPhPO mixtures in 1,2-dichloroethane at [HP] $=0.02$ $\mathrm{M},[\mathrm{L}]=0.005 \mathrm{M}$ and $\mathrm{pH}=2.0$.

The data in Figure 1 suggest that mixtures containing compounds II or III exhibit the highest synergistic effect. The introduction of ethyl group into the $o$-phenylene fragment of compound II is not appreciably influence on the Ln(III) extraction with compound III, though is accompanied by an increase of compound III hydophobicity. The replacement of $\mathrm{P}(\mathrm{O}) \mathrm{Ph}_{2}$ group in the molecule of compound III by $\mathrm{C}(\mathrm{O}) \mathrm{NOct}_{2}$ one leads to a decrease of $\mathrm{Ln}(\mathrm{III})$ extraction with compound VIII, which suggests that the $\mathrm{P}(\mathrm{O})$ group has a higher complexation ability than the $\mathrm{C}(\mathrm{O})$ group. The replacement of the $o$-phenylene fragment in the compound II molecule by a dimethylene one causes a decrease of $\operatorname{Ln}(\mathrm{III})$ extraction with compound VII. A higher extraction efficiency of compound II as compared with that of podand VII was explained both by the delocalization of the electron density from the phenylene group to the metal-connected chelate cycle and an increase in the conformational rigidity of compound II molecule, which facilitates the formation of a more stable $\operatorname{Ln}(\mathrm{III})$ complex. ${ }^{28}$ An increase in alkylene bridge between $\mathrm{P}(\mathrm{O})$ group and ether oxygen atom (compounds IV and $\mathbf{V}$ ) as well as an increase in the distance between the phosphoryl group and the $o$-phenylene fragment (compound VI) violates the conditions favorable for the formation of chelate cycles and thus leads to a decrease of the $\operatorname{Ln}$ (III) extraction with mixtures of HP and compounds IV-VI (Figure 1).

It should be noted that the difference in the synergistic efficiency of compounds II or III and other studied compounds decreases from $\mathrm{La}(\mathrm{III})$ to $\mathrm{Lu}(\mathrm{III})$, i.e. with an increase of their atomic number $(\mathrm{Z})$. Thus, the ratio $\mathrm{D}_{\mathrm{Ln}}(\mathbf{I}-$ II) $/ \mathrm{D}_{\mathrm{Ln}}(\mathrm{VIII})$ decreases in the lanthanide series from 467 for $\mathrm{La}(\mathrm{III})$ to 4.0 for $\mathrm{Lu}(\mathrm{III})$ and the ratio $\mathrm{D}_{\mathrm{Ln}}(\mathrm{II}) / \mathrm{D}_{\mathrm{Ln}}(\mathrm{VII})$ decreases from 57 for $\mathrm{La}(\mathrm{III})$ to 1.6 for $\mathrm{Lu}(\mathrm{III})$. Evidently, the synergistic extraction of light $\operatorname{Ln}(\mathrm{III})$ ions is most sensitive to changes in the neutral synergistic structure.

The effect of an organic diluent on the synergistic extraction of $\mathrm{Ln}$ (III) ions with mixtures of HP and compound III was also studied. The data in Figure 2 show that

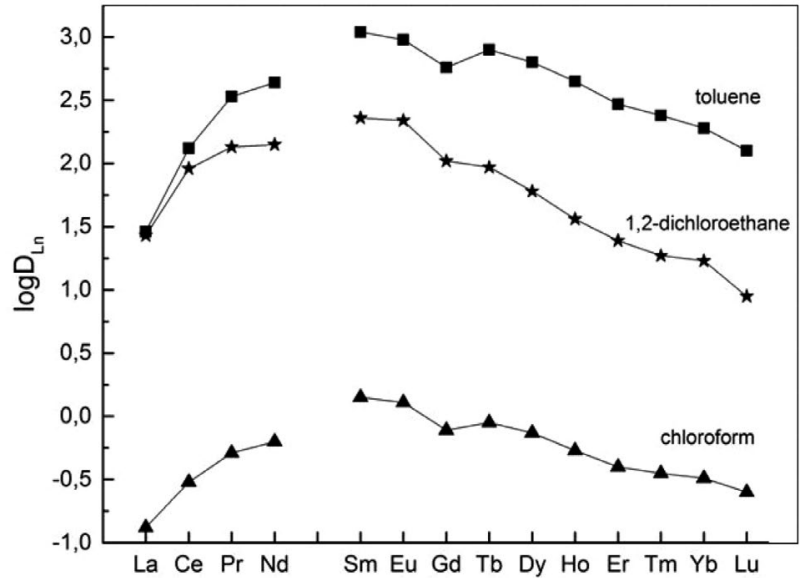

Figure 2. The extraction of lanthanides(III) with HP-compound III mixtures in toluene, 1,2-dichloroethane and chloroform at $[\mathrm{HP}]=$ $0.02 \mathrm{M},[\mathrm{L}]=0.005 \mathrm{M}$ and $\mathrm{pH}=2.0$.

the extraction efficiency increased in the order: chloroform $<1,2$-dichloroethane $<$ toluene. The same tendency was observed at the metal ions extraction with mixtures of acidic chelating extractants and neutral donor compounds. ${ }^{40}$

\section{2. Extraction of Lanthanide(III) Ions with Mixtures of HP and Neutral Ligand III in Toluene}

In the extraction systems with compound III and HP, the plots of $\log D_{\mathrm{Ln}}$ vs. pH exhibited a series of straight lines with slopes close to three (Figure 3 ), which means that three $\mathrm{H}^{+}$ions were released in the extraction reaction.

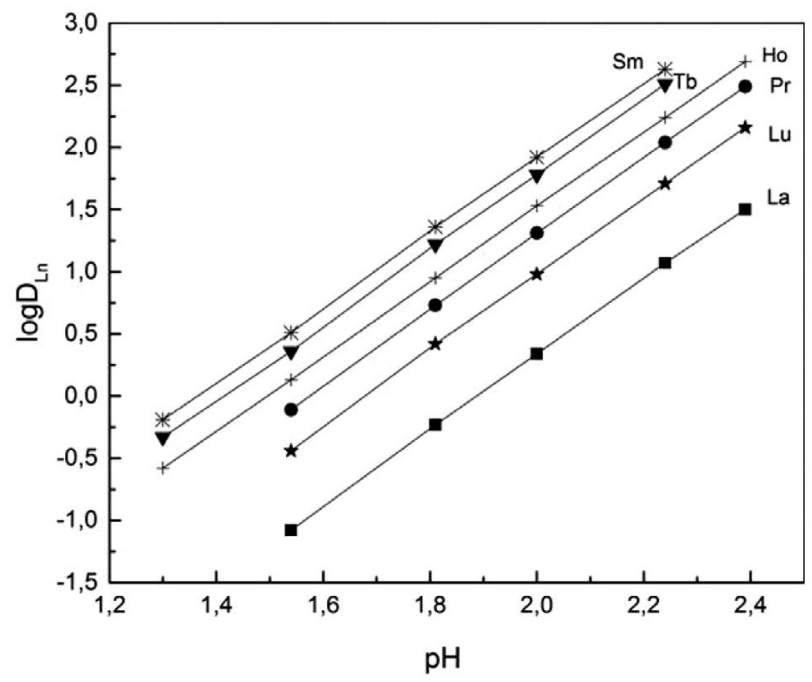

Figure 3. The effect of $\mathrm{pH}$ on the extraction of $\operatorname{Ln}(\mathrm{III})$ with the mixture of $0.001 \mathrm{M}$ compound III and 0.01 M HP in toluene.

The stoichiometry of the Ln(III) extracted complexes in HP-III systems was determined by slope analysis. The plots of $\log D_{\mathrm{Ln}} v s . \log [\mathrm{HP}]$ at a constant $\mathrm{pH}$ and neu- 


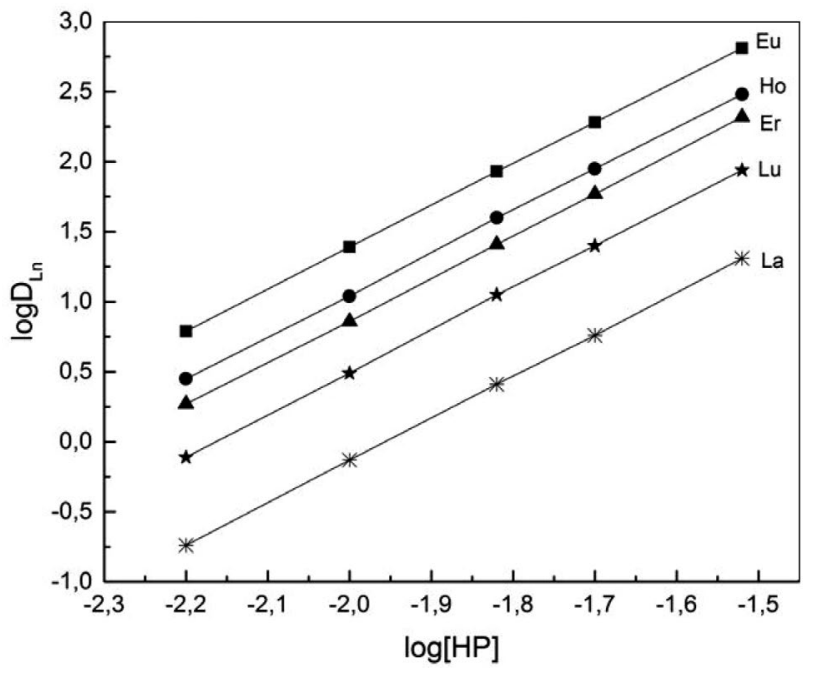

Figure 4. The effect of HP concentration in toluene containing $0.001 \mathrm{M}$ compound III on the extraction of lanthanides(III) at $\mathrm{pH}=$ 2.0 .

tral ligand III concentration in the organic phase are straight lines with slopes close to three (Figure 4).

As the $\operatorname{Ln}(\mathrm{III})$ extraction from aqueous solutions with compound III and $\mathrm{HP}$ alone is negligible $\left(\log D_{\mathrm{Ln}}<\right.$ -2 ) at $\mathrm{pH}=2$, the values of $D_{\mathrm{Ln}}$ obtained experimentally are equal to the distribution ratios due to the synergistic effect. Therefore, the synergistic extraction of $\operatorname{Ln}(\mathrm{III})$ ions can be described by the equation:

$\mathrm{Ln}^{3+}{ }_{(\mathrm{aq})}+3 \mathrm{HP}_{(\mathrm{org})}+\mathrm{sL}_{(\mathrm{org})} \rightleftharpoons \mathrm{LnP}_{3} \mathrm{~L}_{\mathrm{s}(\mathrm{org})}+3 \mathrm{H}^{+}{ }_{(\mathrm{aq})}$

where $s$ is the metal:L stoichiometric ratio.

The variation of $D_{\mathrm{Ln}}$ as a function of the compound III concentration in toluene containing HP is shown in Figure 5.

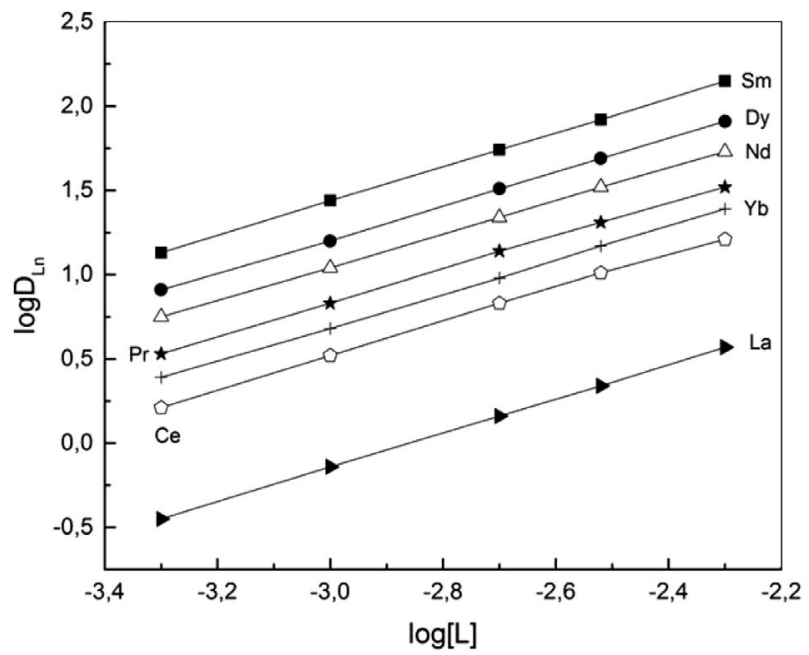

Figure 5. The effect of compound III concentration in toluene containing $0.01 \mathrm{M} \mathrm{HP}$ on the extraction of lanthanides(III) at $\mathrm{pH}=$ 2.0 .
The dependence of $\log D_{\mathrm{Ln}}$ vs. $\log [\mathrm{L}]$ is linear with a slope of $1 \pm 0.02$. Hence, one molecule of neutral donor compound III is involved in the formation of synergistic Ln(III) complexes. The same stoichiometry of the Ln(III) extracted complexes was observed at the extraction with mixtures of HP and phosphorus-containing calix[6] arene. ${ }^{31}$ On the other hand, in the HP - trioctylphosphine oxide (TOPO) system, the formation of $\mathrm{LnP}_{3} \mathrm{TOPO}$ complexes at lower TOPO concentrations and $\mathrm{LnP}_{3}(\mathrm{TOPO})_{2}$ at higher TOPO concentrations was observed. ${ }^{13}$

Assuming that the partition of HP and compound III towards aqueous phase is very low and the polymerization in the organic phase as well as the hydrolysis in the aqueous phase occur only to a negligible extent, ${ }^{37,34}$ the overall equilibrium constant values $\mathrm{K}_{\mathrm{P}, \mathrm{L}}$ can be determined by the equation:

$\log K_{\mathrm{P}, \mathrm{L}}=\log D_{\mathrm{Ln}}-3 \log [\mathrm{HP}]_{(\mathrm{org})}-\log [\mathrm{L}]_{(\mathrm{org})}-3 \mathrm{pH}$

The formation of synergistic adducts in the organic phase can be described by the equation:

$$
\mathrm{LnP}_{3} \mathrm{HP}_{(\text {org })}+\mathrm{L}_{(\text {org })} \rightleftharpoons \mathrm{LnP}_{3} \mathrm{~L}_{(\text {org })}+\mathrm{HP}_{(\text {org })}
$$

The equilibrium constant $\beta_{\mathrm{P}, \mathrm{L}}$ for the adducts formation in the organic phase can calculated using the expression:

$$
\log \beta_{\mathrm{P}, \mathrm{L}}=\log K_{\mathrm{P}, \mathrm{L}}-\log K_{\mathrm{P}}
$$

The values of $K_{\mathrm{P}}$ for the lanthanides(III) extraction with $\mathrm{HP}$ alone in toluene were obtained in the previous work. ${ }^{20}$ The values of the equilibrium constants $K_{P, L}$ and $\beta_{P, L}$ were calculated from the experimental data and are presented in Table 1.Note that these constants are concentration only because they were calculated on the assumption that the activity coefficients of the species involved do not change significantly under the experimental conditions of the present work.

The data presented in Table 1 show that the addition of neutral donor ligand III to the system $\operatorname{Ln}(\mathrm{III})-\mathrm{HP}$ leads to a very large increase of the efficiency of $\operatorname{Ln}(\mathrm{III})$ extraction. The synergistic enhancement produced by mixtures of HP and the studied neutral donor extractant can be determined using a synergistic coefficient $\mathrm{SC}=D_{\mathrm{L}, \mathrm{HP}} /\left(D_{\mathrm{L}}+\right.$ $\left.D_{\mathrm{HP}}\right)$, where $D_{\mathrm{L}}, D_{\mathrm{HP}}$ and $D_{\mathrm{L}, \mathrm{HP}}$ are the distribution ratios of the Ln(III) ion with the two extractants taken separately and with their mixture. The values of SC for $\operatorname{Ln}(\mathrm{III})$ extraction with mixtures of HP and compound III is determined by the stability of $\operatorname{Ln}(\mathrm{III})$ adducts and dependent on the concentration of HP and compound III in organic phase:

$$
\log \mathrm{SC}=\log \beta_{\mathrm{P}, \mathrm{L}}+\log [\mathrm{L}]_{(\mathrm{org})}-\log [\mathrm{HP}]_{(\mathrm{org})}
$$

The data presented in Table 1 show that the extraction ability of HP alone for lanthanide(III) ions increases 
Table 1. Values of the equilibrium constants $K_{\mathrm{P}} K_{\mathrm{P}, \mathrm{L}}, \log \beta_{\mathrm{HP}, \mathrm{L}}$ as well as values of synergistic coefficients SC for $\mathrm{Ln}(\mathrm{III})$ extraction with HP-compound III mixtures in toluene.

\begin{tabular}{lcccc}
\hline $\mathbf{L n}(\mathbf{I I I})$ & $\log \boldsymbol{K}_{\mathbf{P}}[\mathbf{2 0}]$ & $\log \boldsymbol{K}_{\mathbf{P}, \mathbf{L}}$ & $\log \boldsymbol{\beta}_{\mathbf{P}, \mathbf{L}}$ & $\log \mathbf{S C} \mathbf{a}^{\mathbf{a}}$ \\
\hline $\mathrm{La}$ & $-5.56 \pm 0.03$ & $2.86 \pm 0.03$ & $8.42 \pm 0.06$ & 8.12 \\
$\mathrm{Ce}$ & $-4.83 \pm 0.03$ & $3.51 \pm 0.02$ & $8.34 \pm 0.05$ & 8.04 \\
$\mathrm{Pr}$ & $-4.36 \pm 0.03$ & $3.91 \pm 0.03$ & $8.27 \pm 0.06$ & 7.97 \\
$\mathrm{Nd}$ & $-4.08 \pm 0.04$ & $4.03 \pm 0.02$ & $8.11 \pm 0.06$ & 7.81 \\
$\mathrm{Sm}$ & $-3.48 \pm 0.03$ & $4.43 \pm 0.02$ & $7.91 \pm 0.05$ & 7.61 \\
$\mathrm{Eu}$ & $-3.35 \pm 0.03$ & $4.37 \pm 0.02$ & $7.72 \pm 0.05$ & 7.42 \\
$\mathrm{Gd}$ & $-3.44 \pm 0.04$ & $4.15 \pm 0.03$ & $7.59 \pm 0.07$ & 7.29 \\
$\mathrm{~Tb}$ & $-3.17 \pm 0.03$ & $4.29 \pm 0.02$ & $7.46 \pm 0.05$ & 7.16 \\
$\mathrm{Dy}$ & $-3.06 \pm 0.04$ & $4.19 \pm 0.02$ & $7.25 \pm 0.06$ & 6.95 \\
$\mathrm{Ho}$ & $-3.07 \pm 0.03$ & $4.04 \pm 0.02$ & $7.11 \pm 0.05$ & 6.81 \\
$\mathrm{Er}$ & $-2.94 \pm 0.03$ & $3.86 \pm 0.03$ & $6.80 \pm 0.06$ & 6.50 \\
$\mathrm{Tm}$ & $-2.67 \pm 0.03$ & $3.77 \pm 0.02$ & $6.44 \pm 0.05$ & 6.14 \\
$\mathrm{Yb}$ & $-2.43 \pm 0.04$ & $3.67 \pm 0.03$ & $6.10 \pm 0.07$ & 5.80 \\
$\mathrm{Lu}$ & $-2.46 \pm 0.03$ & $3.49 \pm 0.02$ & $5.95 \pm 0.05$ & 5.65 \\
\hline \multicolumn{2}{c}{ a) $[\mathrm{HP}]=0.01 \mathrm{M},[\mathbf{I I I}]=0.005 \mathrm{M}$ and $\mathrm{pH}=2.0$} & &
\end{tabular}

with the increasing atomic number of lanthanides. This can be connected with an increase of the stability of Ln(III) complexes with hard ligands as the $\operatorname{Ln}^{3+}$ ions charge density increase owing to decrease of their ionic radii when $\mathrm{Z}$ rises. In the lanthanides series, the $K_{\mathrm{P}, \mathrm{L}}$ values increases from $\mathrm{La}(\mathrm{III})$ to $\mathrm{Sm}$ (III) and then non-monotonic decrease in $K_{P, L}$ values is observed due to tetrad effect upon the $\operatorname{Ln}(\mathrm{III})$ extraction. ${ }^{41}$ The same character of the $K_{\mathrm{P}, \mathrm{L}}-\mathrm{Z}$ dependency was observed at the $\mathrm{Ln}(\mathrm{III})$ extraction with mixtures of HP and dibutyl-( $N, N$-dibutylcarbamoylmethoxy)phosphine oxide. ${ }^{20}$

The data presented in Table 1 show that the values of $\beta_{\mathrm{P}, \mathrm{L}}$ as well as SC decrease from $\mathrm{La}(\mathrm{III})$ to $\mathrm{Lu}(\mathrm{III})$. A similar tendency was observed for the adduct formation of $\mathrm{LnP}_{3}$ with trioctylphospine oxide, ${ }^{13}$ phosphorus-containing calix[6] arene and dibutyl-( $N, N$-dibutylcarbamoylmethoxy) phosphine oxide. ${ }^{25,20}$ On the other hand, an increase of the $\beta$ values from $\mathrm{La}(\mathrm{III})$ to $\mathrm{Lu}(\mathrm{III})$ was observed by Atanassova and Dukov in the HP-1-(2-pyridylazo)-2-naphtol synergistic system. ${ }^{42}$

\section{Conclusions}

Synergetic solvent extraction of lanthanide (III) ions with mixtures of 4-benzoyl-3-methyl-1-phenyl-5-pyrazolone and neutral phosphoryl-containing podands has been studied. The structure of phosphoryl-containing podands has a considerable effect on their extraction efficiency. In combination with HP, compounds II and III exhibit the highest synergistic effect. A remarkably large synergistic effect (more than 5-8 order of magnitude) was observed for the $\mathrm{Ln}(\mathrm{III})$ ions extraction with mixtures of $\mathrm{HP}$ and III in toluene from weak acidic $\mathrm{HCl}$ solutions. This effect is associated with the replacement of HP in self-adducts $\mathrm{LnP}_{3} \mathrm{HP}$ by neutral donor ligand III. The stoichiom- etry of the Ln(III) extracted complexes in the HP-III system was determined by slope analysis and the equilibrium constants were calculated.

The study was carried out within the framework of a state assignment of the Institute of Solid State Physics, Institute of Microelectronics Technology and High Purity Materials, the Institute of Physiologically Active Compounds the Frumkin Institute of Physical Chemistry and Electrochemistry, Russian Academy of Sciences, and partial supported by the Russian Foundation for Basic Research (project no. 18-29-24069) and program of competitive recovery of National University of Science and Technology MISiS (project no. K2-2016-070).

\section{References}

1. K. L. Nash, M. P. Jensen, Analytical separations of lanthanides: basic chemistry and methods. In Handbook on the Physics and Chemistry of Rare Earths; Gschnedner, K.A., Eyring, L. (Eds.). Elsevier Scince B.V., 2000; Vol. 28, 311-371. DOI:10.1016/S0168-1273(00)28008-2

2. G. J. Lumetta, A. V. Gelis, G. F. Vandegrift, Solvent Extr. Ion Exch. 2010, 28, 287-312. DOI:10.1080/07366291003684253

3. A. H. Bond, M. L. Dietz, R. Chiarizia, Ind. Eng. Chem. Res. 2000, 39, 3442-3464. DOI:10.1021/ie000356j

4. S. Nakamura, S. Takai, K. Akiba, Anal. Sci. 2002, 18, 319-323. DOI:10.2116/analsci.18.319

5. I. Matsubayshi, Y. Hasegawa, Anal. Sci. 2001, 17, 221-223. DOI:10.1111/j.1477-9730.2001.tb01580.x

6. M. A. Petrova, J. Chem. Eng. Data 2010, 55, 5791-5796. DOI:10.1021/je100733k

7. S. K. Sahu, V. Chakravortty, M. L. P. Reddy, T. R. Ramamohan, Radiochim. Acta 1999, 85, 107-111.

8. M. Atanassova, I. Dukov, J. Solution Chem. 2009, 38, 289-301. DOI:10.1007/s10953-009-9374-7 
9. R. Pavithran, L. R. Varma, M. L. P. Reddy, Solvent Extr. Ion Exch. 2003, 21, 797-813. DOI:10.1081/SEI-120025924

10. M. Atanassova, I. Dukov, Sep. Sci. Technol. 2005, 40, 11031113. DOI:10.1081/SS-200049855

11. M. Atanassova, I. Dukov, Acta Chim. Slov. 2006, 53, 457-463.

12. Y. Sasaki, G. R. Choppin, J. Radioanal. Nucl. Chem. 1996, 207, 383-394. DOI:10.1007/BF02071243

13. H. Mukai, S. Umetani, M. Matsui, Solvent Extr. Ion Exch. 2003, 21, 73-90. DOI:10.1081/SEI-120017548

14. P. B. Santhi, M. L. P. Reddy, T. R. Ramamohan, A. D. Damodaran, Solvent Extr. Ion Exch. 1994, 12, 633-650. DOI:10.1080/07366299408918229

15. J. Zhao, S. Meng, D. Li, J. Chem. Technol. Biotechnol. 2006, 81,1384-1390. DOI:10.1002/jctb. 1572

16. M. A. Petrova, V. Kurteva, L. A. Lubenov, Ind. Eng. Chem. Res. 2011, 50, 12170-12176. DOI:10.1021/ie201207n

17. M. A. Carey, C. V. Banks, J. Inorg. Nucl. Chem. 1969, 31, 533550. DOI:10.1016/0022-1902(69)80497-5

18. A. N. Turanov, V. K. Karandashev, Solvent Extr. Ion Exch. 2017, 35, 104-116. DOI:10.1080/07366299.2017.1288044

19. L. Rao, Y. Xia, B. R. Rapko, P. F. Martin, Solvent Extr. Ion Exch. 1998, 16, 913-929. DOI:10.1080/07366299808934560

20. A. N. Turanov, V. K. Karandashev, A. V. Kharlamov, N. A. Bondarenko, Solvent Extr. Ion Exch. 2014, 32, 492-507. DOI:10.1080/07366299.2014.908584

21. M. Atanassova, V. Lachkova, N. Vassilev, S. Varbanov, I. Dukov, J. Incl. Phenom. Macrocycl. Chem. 2007, 58, 173-179. DOI:10.1007/s10847-006-9140-Z

22. M. Atanassova, V. Lachkova, N. Vassilev, B. Shivachev, S. Varbanov, I. Dukov, Polyhedron 2008, 27, 3306-3312.

DOI:10.1016/j.poly.2008.07.015

23. E. Tashev, M. Atanassova, S. Varbanov, T. Tosheva, S. Shenkov, A.-S. Chauvin, I. Dukov, Sep. Purif. Technol. 2008, 64, 170-175. DOI:10.1016/j.seppur.2008.09.011

24. M. Atanassova, N. Vassilev, E. Tashev, V. Lachkova, S. Varbanov, Sep. Sci. Technol. 2016, 51, 49-56.

DOI:10.1080/01496395.2015.1078358

25. S. Varbanov, E. Tashev, N. Vassilev, M. Atanassova, V. Lachkova, T. Tosheva, S. Shenkova, I. Dukov, Polyhedron 2017, 134, 135-142. DOI:10.1016/j.poly.2017.06.013
26. M. Atanassova, V. Kurteva, RSC Adv. 2016, 6, 11303-11324. DOI:10.1039/C5RA22306G

27. H. Stephan, K. Gloe, J. Beger, P. Muhl, Solvent Extr. Ion Exch. 1991, 9, 435-458. DOI:10.1080/07366299108918063

28. E. I. Sinyavskaya, Koord. Khim. 1986, 12, 1155-1161.

29. A. N. Turanov, V. K. Karandashev, V. E. Baulin, Solvent Extr. Ion Exch. 1999, 17, 1423-1444.

DOI:10.1080/07366299908934656

30. A. N. Turanov, V. K. Karandashev, V. E. Baulin, Russ. J. Iorg. Chem. 2006, 51, 1829-1835. DOI:10.1134/S0036023606110210

31. A. N. Turanov, V. K. Karandashev, D. V. Baulin, V. E. Baulin, A. Y. Tsivadze, Russ. J. Iorg. Chem. 2019, 64, 407-413. DOI:10.1134/S0036023619030203

32. E. N. Tsvetkov, V. K. Syundyukova, V. E. Baulin, Bull. Acad. Sci. USSR. Div. Chem. Sci. 1989, 38, 135-149. DOI:10.1007/BF00953718

33. A. N. Turanov, V. K. Karandashev, V. E. Baulin, A. N. Yarkevich, Z. V. Safronova, Solvent Extr. Ion Exch. 2009, 27, 551-578. DOI:10.1080/07366290903044683

34. S. V. Demin, S. E. Nefedov, V. I. Zhilov, V. E. Baulin, A. Y. Tsivadze Russ. J. Inorg. Chem. 2012, 57, 897-902. DOI:10.1134/S0036023612060095

35. E. N. Tsvetkov, V. I. Evreinov, V. E. Baulin, V. V. Ragulin, N. A. Bondarenko, Z. N. Vostroknutova, Z. V. Safronova, Russ. J. Gen. Chem. 1995, 65, 1300-1307.

36. V. I. Evreinov, V. E. Baulin, Z. N. Vostroknutova, N. A. Bondarenko, V. K. Syundyukova, E. N. Tsvetkov, Izv. Akad. nauk SSSR, Ser. Khim. (in Russian) 1989, 9, 1990-1997.

37. Y. A. Zolotov, N. M. Kuzmin, Metal extraction with acylpyrazolones. Nauka. Moscow. 1977.

38. V. M. Jordanov, M. Atanasova, I. L. Dukov, Sep. Sci. Technol. 2002, 37, 3349-3353. DOI:10.1081/SS-120006166

39. M. Atanasova, I. L. Dukov, Sep. Purif. Technol. 2004, 40, 171176. DOI:10.1016/j.seppur.2004.02.007

40. K. Akiba, M. Wada, T. Kanno, J. Inorg. Nucl. Chem. 1981, 43, 1031-1034. DOI:10.1016/0022-1902(81)80169-8

41. I. Fidelis, S. Siekierski, J. Inorg. Nucl. Chem. 1971, 33, 31913194. DOI:10.1016/0022-1902(71)80092-1

42. M. Atanasova, I. L. Dukov, Sep. Purif. Technol. 2006, 49, 101105. DOI:10.1016/j.seppur.2005.09.001

\section{Povzetek}

Proučevali smo ekstrakcijo La, Ce, Pr, Nd, Sm, Eu, Gd, Tb, Dy, Ho, Er, Tm, Yb, in Lu ionov iz šibko kisle raztopine s kloridnimi ioni v organsko fazo, ki vsebuje 4-benzoil-3-metil-1-fenil-5-pirazolon (HP) in fosforil-vsebujoče podande (L). Opažen je bil izrazit sinergistični efekt ob prisotnosti nevtralnega liganda L v organski fazi, ki vsebuje HP. Stehiometrijo Ln(III) ekstrahiranih zvrsti smo določili iz naklonskega kota premic v diagramih ter izračunali ravnotežno konstanto. Lantanidni(III) ioni se ekstrahirajo v toluen s prisotnima HP in nevtralnim ligandom iz šibko kisle raztopine kot $\mathrm{LnLP}_{3}$ kompleksi.

Except when otherwise noted, articles in this journal are published under the terms and conditions of the Creative Commons Attribution 4.0 International License 